\title{
Warunki trójstronnego dialogu społecznego
}

\section{Wprowadzenie}

C) sięga Jubileuszowa dedykowana Profesorowi Michałowi SeweryńUskiemu dotyczy przyszłości prawa pracy w Polsce. Zgodnie z dobrym zwyczajem artykuł zamieszczony w Księdze Jubileuszowej powinien nawiązać do dorobku Jubilata, a jego treścią winien być temat związany z tym dorobkiem. Temat Księgi tylko pozornie utrudnia realizację tego zwyczaju

Przyszłość prawa pracy w Polsce to zagadnienie poważne, bardzo szerokie, skłaniające nas do refleksji nad obecnym stanem prawa pracy w Polsce, nad ewentualną koniecznością dokonania zmian, określenia kierunków i zakresu tych zmian. Upłynęło czterdzieści lat od wejścia w życie kodeksu pracy, trzydzieści pięć lat od powstania społecznego i związkowego ruchu "Solidarność" i ponad dwadzieścia pięć lat od rozpoczęcia przemian ustroju politycznego i gospodarczego w 1989 r. Istotne znaczenie ma nie tylko upływ czasu, ale także zakres i znaczenie zmian zaistniałych po roku 1989.

Nasuwa się wiele pytań. Czy udało nam się wprowadzić w życie zasady prawne, które głosiliśmy w roku 1980 i 1981, i które później wprowadzaliśmy, dokonując przełomu ustrojowego po roku 1989? Co nam się udało, a co budzi refleksje krytyczne? Czy powinniśmy zmienić dzisiejszy model prawa pracy w Polsce? A jeśli tak, to w jakim kierunku i opierając się na jakich wartościach, które powinny decydować o przyszłym kształcie tej dziedziny prawa. By odpowiedzieć na te pytania powinniśmy dokonać głębokiej oceny obowiązujących rozwiązań prawnych i praktyki stosowania prawa pracy. Nie można omawiać przyszłości prawa pracy

* Dr hab., Uniwersytet Ekonomiczny w Katowicach. 
w oderwaniu od refleksji historycznej. W nauce prawa dostrzega się i docenia potrzebę badania zjawisk prawnych w sposób historyczny, uwzględniający ich genezę i rozwój ${ }^{1}$.

Za dokonaniem poważnych zmian przemawia fakt, że nie udało się doprowadzić do takiej kodyfikacji prawa pracy, która uwzględniałaby wprowadzone po 1989 r. fundamentalne zmiany ustroju politycznego, społecznego i gospodarczego. Kodeks pracy z roku 1974 był przygotowywany pod naciskiem i kontrolą ówczesnych władz Polski. Jego rozwiązania dotyczyły aktualnego $\mathrm{w}$ tym czasie, niedemokratycznego systemu politycznego, któremu była podporządkowana scentralizowana, nieefektywna gospodarka. Kodeks pracy zawierał prawne regulacje stosunków pracy w dużym przedsiębiorstwie państwowym z jednym związkiem zawodowym, który nie reprezentował i nie bronił praw i interesów pracowników. Konieczne więc było dokonanie fundamentalnych zmian w prawie pracy, a zbiorowe prawo pracy trzeba było budować od nowa.

Za koniecznością zmian przemawiają też inne argumenty, które zostaną przedstawione poniżej, w punkcie trzecim niniejszego rozdziału.

\section{Próby kodyfikacji polskiego prawa pracy}

Kilkakrotnie podejmowane były próby kodyfikacji kodeksu pracy, a następnie także kodeksu zbiorowego prawa pracy. Profesor M. Seweryński bardzo aktywnie uczestniczył we wszystkich pracach kodyfikacyjnych.

Był współautorem opracowania Kierunki reformy prawa pracy², które stanowiło podstawę i było immanentną częścią Społecznego projektu tez nowelizacji kodeksu pracy. Był współautorem tego projektu, przygotowanego w 1981 r. przez Ośrodek Prac Społeczno-Zawodowych ${ }^{3}$ w Warszawie (ko-

${ }^{1}$ W. Szubert, Histoire du droit et les recherches sur le droit contemporain, "Czasopismo Prawno-Historyczne" 1979, t. XXXI, z. 1 oraz T. Zieliński, Podstawy rozwoju praw pracy, rozdz. VI - Czynnik historyczny w rozwoju prawa pracy, PWN, Warszawa-Kraków 1988, ss. 84-99; idem, Interpretacja historyczna w porównawczym prawie pracy, [w:] Studia z prawa pracy. Dla uczczenia 50-lecia działalności naukowej Profesora Doktora Wacława Szuberta, PWN, Warszawa-Łódź 1988, ss. 395-407.

2 J. Nowacki, M. Pliszkiewicz, J. Rosner, M. Seweryński, W. Szubert, T. Zieliński, Kierunki reformy prawa pracy. Założenia ogólne, Instytut Wydawniczy Związków Zawodowych, Wyd. I i II, Warszawa 1981. Wydanie II ukazało się na zlecenie Ośrodka Prac Społeczno-Zawodowych przy Komisji Krajowej Porozumiewawczej NSZZ Solidarność jako oficjalny dokument na I Krajowy Zjazd NSZZ Solidarność we wrześniu 1981 r. Opracowanie to przedstawiłem na V Seminarium Szubertowskim 28.11.2015. Jest ono przedmiotem osobnego artykułu.

3 Zgodnie z § 35.1 Statutu NSZZ Solidarność z 1980 r. został powołany Ośrodek Prac Społeczno-Zawodowych (OPSZ) prowadził badania nad warunkami życia i pracy, jak również kosztami utrzymania ogółu pracowników oraz przygotowywał ekspertyzy w zakresie polityki społeczno-gospodarczej na potrzeby Związku. 
ordynatorem prac był M. Pliszkiewicz) i Krajową Komisję Koordynacyjną NSZZ „Solidarność" Pracowników Wymiaru Sprawiedliwości - Centrum Obywatelskich Inicjatyw Ustawodawczych w Krakowie (koordynatorem prac był T. Zieliński). Obydwie te instytucje działały pod kierunkiem Krajowej Komisji Porozumiewawczej NSZZ „Solidarność" ${ }^{4}$ w Gdańsku (KKP "S"), najwyższego organu władzy wykonawczej Związku.

Następnie Profesor Seweryński był członkiem i przewodniczącym Zespołu tematycznego Wynagrodzenie za pracę i inne świadczenia oraz układ zbiorowy pracy, Komisji do spraw Reformy Prawa Pracy, powołanej zarządzeniem nr 37 Prezesa Rady Ministrów z dnia 4 września 1981 r. Ostateczny skład Komisji został ustalony w wyniku rozmów pomiędzy Ministerstwem Pracy, Płac i Spraw Socjalnych (MPPiSS) oraz Krajową Komisją Porozumiewawczą NSZZ „Solidarność".

Członkowie Komisji, oprócz wspomnianego Społecznego projektu tez nowelizacji kodeksu pracy, otrzymali na swoim pierwszym posiedzeniu w dniu 14 września 1981 r. Projekt ustawy zmieniającej ustawe Kodeks pra$c y$, przygotowany przez MPPiSS. Komisja podjęła decyzje, że jej prace będą się toczyły nad tezowym Społecznym projektem tez nowelizacji kodeksu pracy $^{5}$, który - jak stwierdzono - był czytelniejszy niż bardzo techniczny Projekt MPPiSS. Komisja zakończyła prace nad nowym Projektem Kodeksu pracy na początku grudnia 1981 r. Projekt ten miał być przyjęty na ostatnim posiedzeniu $\mathrm{w}$ połowie grudnia 1981 r., nie odbyło się ono jednak ze względu na wprowadzenie w Polsce 13 grudnia 1981 r. stanu wojennego.

Profesor M. Seweryński brał udział i kierował pracami kodyfikacyjnymi po 1989 r. Był wiceprzewodniczącym, powołanej na początku lat dziewięćdziesiątych w MPPiSS, Komisji do Spraw Reformy Prawa Pracy i Ubezpieczeń Społecznych. W łonie tej Komisji był autorem Projektu Kodeksu zbiorowego prawa pracy.

Zdaniem Andrzeja Bączkowskiego, ówczesnego wiceministra a potem ministra pracy i polityki socjalnej Kodeks Pracy z 1974 r. regulujący, poza Działem XI, indywidualne stosunki pracy mógł, po przeprowadzonej w 1996 r. szerokiej nowelizacji, funkcjonować w nowych warunkach ustrojowych. W okresie przed 1989 r. nie istniały w Polsce zbiorowe stosunki pracy w rozumieniu standardów Międzynarodowej Organizacji Pracy. Pilnym zadaniem było stworzenie nowej regulacji prawnej zbiorowych stosunków pracy, która uwzględniałaby dokonywane zmiany i nasze zobowiązania międzynarodowe, zwłaszcza wobec Wspólnot Europejskich.

${ }^{4}$ Od września 1981 r. Krajowa Komisja Porozumiewawcza zmieniła nazwę na Komisję Krajową NSZZ „Solidarność".

${ }^{5}$ Na temat Społecznego projektu tez nowelizacji kodeksu pracy i prac i Komisji do spraw Reformy Prawa Pracy z 1981 r. jest przygotowywany odrębny artykuł. 
16 grudnia 1991 r. został podpisany Układ Europejski ustanawiający stowarzyszenie między Rzeczpospolitą Polską z jednej strony a Wspólnotami Europejskimi i ich państwami członkowskimi z drugiej strony ${ }^{6}$. Zgodnie $\mathrm{z}$ art. 68 tego Układu ,strony uznaja, że istotnym warunkiem wstępnym integracji gospodarczej Polski ze Wspólnotą jest zbliżanie istniejącego i przyszłego ustawodawstwa Polski do ustawodawstwa istniejącego we Wspólnocie. Polska podejmie wszelkie starania w celu zapewnienia zgodności jej przyszłego ustawodawstwa z ustawodawstwem Wspólnoty".

Dlatego prace nad przygotowaniem Projektu Kodeksu zbiorowego prawa pracy minister A. Bączkowski powierzył wybitnemu znawcy prawa europejskiego i porównawczego, Profesorowi Michałowi Seweryńskiemu.

Warto podkreślić wzorcowy sposób prowadzenia prac nad tym Projektem. Zazwyczaj rola autora projektu aktu prawnego kończy się z chwilą przekazania go właściwemu ministrowi lub innemu organowi mającemu prawo inicjatywy ustawodawczej. Następnie projekt podlega zmianom wynikającym z dalszych prac (uzgodnienia międzyresortowe, opiniowanie założeń i projektów aktów prawnych przez partnerów społecznych, dyskusje nad zgłoszonymi uwagami i poprawkami etc.). Często się zdarza, że pierwotny, spójny projekt, przygotowany według określonych założeń jest niekorzystnie zmieniany. W przypadku omawianego Projektu 464 Kodeksu zbiorowego prawa pracy jego Autor cały czas uczestniczył w pracach Komisji do Spraw Reformy Prawa Pracy i Ubezpieczeń. Ustosunkowywał się do zgłaszanych przez członków Komisji uwag, zwracając uwagę na konsekwencje wprowadzenia proponowanych zmian dla jedności i spójności Kodeksu. Na podstawie zgłoszonych propozycji przedstawiał, zazwyczaj na następnym posiedzeniu, często wariantowo nową redakcję danego przepisu. Ten tryb prac prowadzony był aż do ukończenia Projektu. Warto o nim pamiętać, gdyż wzbudził on zainteresowanie naszych zagranicznych partnerów, w tym Departamentu Stanu USA.

W 1997 r. Projekt został ukończony, ale wskutek protestów NSZZ Solidarność i Ogólnopolskiego Porozumienia Związków Zawodowych (OPZZ) nie został skierowany do dalszych prac legislacyjnych. Przyczyną tych protestów był Dział piąty tego Projektu - Prawa załogi zakładu pracy i jego rozdział 2 Rada zakładowa. Regulował on obowiązujące w świetle prawa europejskiego zagadnienia utworzenia reprezentacji załogi. Polskie związki zawodowe uważały, że jest to dla nich konkurencja ${ }^{8}$.

${ }^{6}$ Układ wszedł w życie 1 lutego $1994 \mathrm{r}$.

7 Tekst gotowego Projektu Kodeksu zbiorowego prawa pracy został opublikowany w materiałach Ministerstwa Pracy i Spraw Socjalnych we wrześniu 1997 r.

${ }^{8}$ Obecnie sprawa reprezentacji załogi jest regulowana Ustawą z dnia 7 kwietnia 2006 o informowaniu pracowników i przeprowadzaniu z nimi konsultacji (DzU, 2006, nr 79, poz. 550). 
Profesor M. Seweryński był wiceprzewodniczącym, a po śmierci Profesora T. Zielińskiego, przewodniczącym Komisji Kodyfikacyjnej Prawa Pracy ${ }^{9}$. Prace nad Projektami Kodeksu pracy i Zbiorowego kodeksu pracy zostały zakończone w 2004 r., ale nie zostały one skierowane do Sejmu. Opublikowano je jednak ${ }^{10}$.

Zdaję sobie sprawę z faktu, że w obecnej sytuacji politycznej i społecznej trudno byłoby podjąć w Sejmie prace nad kodyfikacją. Przedstawiciele nauki prawa pracy moga mimo to $\mathrm{w}$ swoich badaniach kontynuować - bo mamy projekty kodeksu zbiorowego prawa pracy z 1997 r. oraz kodeksu pracy i zbiorowego kodeksu pracy z 2004 r. - prace nad tą kodyfikacją. Upływ czasu oraz zakres i znaczenie dokonanych zmian skłaniaja, a nawet zmuszają naukę prawa pracy do dokonania, stopniowo, oceny obecnie obowiązującego prawa pracy. Powinniśmy być przygotowani do szybkich działań legislacyjnych, gdy sytuacja polityczna i gospodarcza będzie sprzyjała pracom kodyfikacyjnym.

Przypomnę pewne fakty z lat osiemdziesiątych i dziewięćdziesiątych. W roku 1980, po powstaniu NSZZ Solidarność, pojawiła się możliwość zmian, a my nie byliśmy na to przygotowani. Nie było gotowych opracowań ani projektów aktów z różnych dziedzin prawa. Braki te nadrabialiśmy bardzo intensywna pracą. Cytowany wyżej Społeczny projekt tez nowelizacji kodeksu pracy powstał w ciągu kilku miesięcy. Po wprowadzeniu stanu wojennego, wymieniony wyżej zespół autorski, który przygotował Kierunki reformy prawa pracy. Założenia ogólne ${ }^{11}$, postanowił dalej spotykać się i pracować nad zmianami prawa pracy. Efektem była dyskusja nad opracowaniem M. Pliszkiewicza pt. Prawo pracy stanu wojennego ${ }^{12}$. Niestety po pewnym czasie zakończyliśmy nasze dyskusje i prace. W $1989 \mathrm{r}$. znów nie mieliśmy gotowych projektów. W efekcie Polska, która pierwsza rozpoczęła zmiany ustrojowe w Europie, ważne akty prawne przyjmowała później niż inne kraje Europy Środkowej i Wschodniej. Na Węgrzech Konstytucja z 1949 r. została zmieniona w 1989 r. Nowe Konstytucje przyjęto w Bułgarii i w Rumunii w 1991 r., w Czechach i Słowacji w roku 1992, a w Polsce dopiero w 1997 r. $^{13}$

9 Powołanej rozporządzeniem Rady Ministrów z 20.08.2002 (DzU, 2002, nr 139, poz. 1167).

${ }^{10}$ W 2008 r. na stronie internetowej MPIPS, a następnie drukiem: Kodeks pracy. Zbiorowy kodeks pracy, Wyd. Uniwersytetu Ekonomicznego w Katowicach, Katowice 2010.

${ }^{11}$ Supra, przyp. 2.

12 Opracowanie pozostało opublikowane w tzw. drugim obiegu poza cenzura, ale ze względu na konieczność zachowania konspiracji egzemplarz autorski nie dotarł do autora.

${ }_{13}$ Patrz M. Pliszkiewicz, Podstawowe problemy rozwoju prawa pracy w Europie Środkowo-Wschodniej, [w:] Nowy lad pracy w Polsce i w Europie, red. M. Matey, Wydawnictwo Naukowe „Scholar”, Warszawa 1997, s. 188-191. 
W nauce prawa pracy w ostatnich latach poświęcono wiele uwagi zasadniczym problemom prawa pracy. Dwa ostatnie Zjazdy Katedr Prawa Pracy i Ubezpieczeń Społecznych w roku 2013 w Poznaniu ${ }^{14}$ i w 2015 r. $\mathrm{w}$ Lublinie $^{15}$ były poświęcone problematyce aksjologii $\mathrm{w}$ prawie pracy. Świadczy to o odczuwalnej potrzebie przedstawicieli nauki prawa pracy prowadzenia dyskusji naukowej nad najważniejszymi problemami tej dziedziny prawa. Jest to dobry kierunek. Opracowania te na pewno pomogą w przyszłości w kodyfikacji polskiego prawa pracy.

\section{Potrzeba dokonania zmian $\mathrm{w}$ zbiorowym prawie pracy $w$ Polsce}

Warto poświęcić trochę uwagi następującym zagadnieniom: dlaczego należy w pierwszej kolejności dokonać oceny problemów prawa pracy (3.1) oraz jakie argumenty przemawiają za potrzebą dokonania zmian (3.2).

\subsection{Znaczenie zbiorowego prawa pracy}

Po pierwsze trzeba podkreślić ogromne znaczenie tej dziedziny prawa pracy. „System prawa pracy ukształtowany w czasach nowożytnych wyraża przede wszystkim układ powiązań prawnych pomiędzy trzema podmiotami, które stanowią: pracownik, pracodawca i państwo. W tym trójkącie kształtują się podstawowe treści prawa pracy, decydujące o jego społecznym obliczu i charakterze" ${ }^{16}$.

Wśród czynników, które wpływają w sposób zasadniczy na prawo pracy, należy wymienić układ sił pomiędzy pracownikami i reprezentującymi ich organizacjami a pracodawcami i ich organizacjami, a także czynniki polityczne, ekonomiczne i społeczne ${ }^{17}$.

Ta myśl przyświecała autorom ustawy o Komisji Trójstronnej, która „stanowi forum dialogu społecznego prowadzonego dla godzenia interesów pracowników, interesów pracodawców oraz dobra publicznego", a „celem działalności Komisji jest dążenie do osiągnięcia i zachowania

${ }^{14}$ Patrz Aksjologiczne podstawy prawa pracy i ubezpieczeń społecznych, Redakcja naukowa M. Skąpski, K. Ślebzak, Wydawnictwo Ars boni et aequi, Poznań 2014.

${ }^{15}$ Temat Zjazdu: Równość i sprawiedliwość w zatrudnieniu.

${ }^{16}$ W. Szubert, Refleksje nad modelami prawa pracy, „Państwo i Prawo” 1989, nr 10, s. 5.

17 J. Rivero, J. Savatier, Droit du travail, PUF, Paris 1991, s. 34-36, 30-42; J.-C. Javillier, Dynamique des relations professionelles et évolution du droit du travail, [w:] Le droit collectif du travail (questions fondamentales - évolutions récentes), Etudes en hommage à Madame Hélène Sinay, eds N. Aliprantis, F. Kessler, Frankfurt am Main-Berlin-Bern-New York-ParisWien 1994, s. 219 i nast. 
pokoju społecznego"18. Na wzajemną współzależność działań i interesów tych trzech podmiotów zwrócił uwagę M. Seweryński przy omawianiu efektywności i skuteczności prawa pracy ${ }^{19}$.

Dialog społeczny, a zwłaszcza trójstronny dialog społeczny, jest bardzo ważny dla całego prawa pracy. Polska ratyfikowała Konwencje nr 87 i nr 98 Międzynarodowej Organizacji Pracy ${ }^{20}$, określające standardy międzynarodowe w zakresie swobody tworzenia i działania związków zawodowych i organizacji pracodawców. Prowadzona od lat pięćdziesiątych walka o prawo do tworzenia niezależnych od władzy, samorządnych związków zawodowych była symbolem walki o demokrację ${ }^{21}$.

Po drugie - Profesor M. Seweryński poświęcił problematyce zbiorowych stosunków pracy i dialogu społecznego szczególnie dużo miejsca w swoich badaniach naukowych i w publikacjach w kraju i za granica, a także w swej pracy społecznej. Jego dokonań było tak wiele, że nie można ich omówić w krótkim artykule. Tu podam tylko jeden przykład. Ta właśnie tematyka była przedmiotem referatów generalnych wygłoszonych przez niego w czasie kongresów Międzynarodowego Stowarzyszenia Prawa Pracy i Zabezpieczenia Społecznego w 1989 r. w Paryżu22, w 1996 r. w Leiden ${ }^{23}$ i w 1999 r. w Warszawie ${ }^{24}$.

\subsection{Konieczność zmian w zakresie zbiorowego prawa pracy}

Można podać kilka argumentów na poparcie tezy, że potrzebna jest zmiana zbiorowego prawa pracy. Po pierwsze - ta dziedzina prawa, uzależniona od przemian ekonomicznych i społecznych, podlega szczególnie częstym zmianom. Dynamika rozwojowa prawa pracy ${ }^{25}$ jest jedną z wła-

18 Art. 1 ust. 1 i 2 ustawy z dnia 6 lipca 2001 o Trójstronnej Komisji do Spraw Społeczno-Gospodarczych i wojewódzkich komisjach dialogu społecznego (DzU, 2001, nr 100, poz. 1080 z późn. zm.).

${ }^{19}$ M. Seweryński, Uwagi o efektywności prawa pracy, [w:] Księga Pamiątkowa w piąta rocznice śmierci Profesora Andrzeja Kijowskiego, red. Z. Niedbała, LEX Wolters Kliwer business, Warszawa 2010, ss. 271-281.

${ }^{20}$ DzU, 1958, nr 29, poz. 125 i 126.

${ }^{21}$ Patrz M. Pliszkiewicz, Dialogue social en Pologne, [w:] Des liens et des Droits, Mélanges en l'honneur de Jean-Pierre Laborde, Ed. Dalloz, Paris 2015, s. 815-827.

${ }_{22}$ M. Seweryński, Les particularités du syndicalisme des pays de l'Est et les tendances récentes dans ce domaine, „Revue Internationale de Droit Comparé” 1990, n 1, ss. 115-127.

${ }^{23}$ M. Seweryński, Prospects for the Development of Labour Law and Social Security Law in Central and Eastern Europe in the Twenty-First Century, [w:] $5^{\text {th }}$ European Regional Congress for Labour Law and Social Security. General Reports, Leiden, The Netherlands 1996.

${ }^{24}$ M. Seweryński, Dialog społeczny. Współzależność gospodarki i prawa pracy, [w:] Referaty na VI Europejski Kongres Prawa Pracy i Zabezpieczenia Społecznego, Wydawnictwo Naukowe "Scholar", Warszawa 1999, s. 12-38.

${ }^{25}$ W. Szubert, Zarys prawa pracy, PWN, Warszawa 1976, ss. 46-48; T. Zieliński, Prawo pracy. Zarys systemu, cz. I, Ogólna, PWN, Warszawa-Kraków 1986, s. 34-37; J. Rivero, J. Savatier, Droit du travail..., s. 34-36, 30-42. 
ściwości, które uwydatniają jego odrębność w stosunku do innych gałęzi prawa. Jej konsekwencją jest potrzeba periodycznej oceny stanu prawnego dla uchwycenia zachodzących zmiany i w odpowiedni sposób na nie zareagowania. Jak już wyżej powiedziano, za dokonaniem poważnych zmian przemawia dobitnie fakt, że nie udało się doprowadzić do kodyfikacji zbiorowego prawa pracy w Polsce.

Po drugie - warto przypomnieć, w jakiej rzeczywistości i w jaki sposób tworzone było zbiorowe prawo pracy po $1989 \mathrm{r}$. Zbiorowe prawo pracy, w rozumieniu standardów międzynarodowych, nie istniało w Polsce przed rokiem 1989. Ta dziedzina została stworzona od podstaw po zmianie ustroju politycznego i gospodarczego.

W Polsce po roku 1989 stworzono demokratyczny ustrój polityczny i gospodarkę rynkową. Należy pamiętać o bardzo trudnych okolicznościach wprowadzania tych zmian (recesja gospodarcza, bardzo wysoka inflacja, bezrobocie, dług zagraniczny, duży spadek realnej wartości wynagrodzeń $)^{26}$. Premier T. Mazowiecki w wystąpieniu w Paryżu na konferencji na temat: Demokracja, kultura i rozwój w Europie Centralnej, stwierdził, iż w początkowym okresie po 1989 r. najcenniejszym dobrem był czas, bo zgodnie z łacińską maksymą: bis dat qui cito dat trzeba było szybko dokonywać bardzo wielu zmian. Czas na dokonanie tych reform był krótki, także ze względu na ograniczony okres cierpliwości i przyzwolenia społeczeństwa na ich dokonywanie ${ }^{27}$. Każdy, kto uczestniczył w ówczesnych pracach legislacyjnych, mógłby podać przykłady przepisów, które od początku były nienależycie zredagowane.

Jak powszechnie wiadomo, zbiorowe stosunki pracy kształtowane są $\mathrm{w}$ praktyce zgodnie $\mathrm{z}$ układem sił pomiędzy związkami zawodowymi i organizacjami pracodawców. Prowadzone przez partnerów społecznych spory i negocjacje kończone podpisaniem porozumień i układów zbiorowych pracy są podstawą prawnej regulacji zbiorowych stosunków pracy. Pożądany jest taki model, w którym praktyka wzajemnych, wielopłaszczyznowych stosunków i ustalenia dokonane przez partnerów społecznych w dziedzinie zbiorowych stosunków pracy, w zakresie należącym do ich kompetencji, są uwzględnione w ustawodawstwie pracy. Niestety nie było to możliwe.

Ze względu na potrzebę dokonania szybkiej legislacji zbiorowych stosunków pracy „ustawodawca był więc zmuszony do znalezienia rozwią-

${ }^{26}$ M. Pliszkiewicz, Vers de nouvelles relations professionneles en Europe de l'Est, [w:] Les relations sociales dans les pays de l'Est, Ed. Institut National du Travail, de l'Emploi et de la Formation Professionnelles, Direction M. Pliszkiewicz, Paris 1994, s. 23 i nast.

${ }_{27}$ T. Mazowiecki, Le temps de produire la démocratie en Pologne, [w:] Démocratie, culture et développement en Europe Centrale, Ed. Confrontations. Société, culture, foi, Paris 1992, s. 13-14. 
zań prawnych, które będą odpowiadały przyszłemu kształtowi zbiorowych stosunków pracy" ${ }^{28}$. Przyjęcie, z konieczności, rozwiązań prawnych antycypujących przyszły kształt zbiorowych stosunków pracy, w tym rozwiązań zapożyczonych z zachodnich systemów prawnych, prowadzi do określonych konsekwencji i trzeba się liczyć z koniecznością częstych zmian przepisów prawnych, aby odpowiadały one rzeczywiście istniejącym stosunkom, a także, aby wyeliminować, nieuchronne przecież $\mathrm{w}$ takiej sytuacji, błędy ${ }^{29}$. Niejednokrotnie były to decyzje „stworzenia regulacji o charakterze pomostowym, na okres transformacji" ${ }^{30}$.

Jak widać już w chwili tworzenia zbiorowego prawa pracy na początku lat dziewięćdziesiątych wiedzieliśmy, że będzie ono podlegało sukcesywnym zmianom.

Po trzecie - ważnym argumentem jest fakt, że głębokich zmian obecnej formuły dialogu społecznego w łonie Trójstronnej Komisji do Spraw Społeczno-Gospodarczych (TKSSG) domagają się reprezentatywni partnerzy społeczni, a zwłaszcza związki zawodowe. Uważają oni, że obecna formuła rozwiązań prawnych dotycząca trójstronnego dialogu społecznego, zawartych w ustawie o Trójstronnej Komisji do Spraw Społeczno-Gospodarczych ${ }^{31}$ już się wyczerpała i konieczna jest nowa ustawa.

Przewodniczący Niezależnego Samorządnego Związku Zawodowego „Solidarność", Ogólnopolskiego Porozumienia Związków Zawodowych i Forum Związków Zawodowych, organizacji związków zawodowych, członków Komisji Trójstronnej wystosowali 26 czerwca 2013 r. obszerny list do Premiera RP Donalda Tuska, w którym negatywnie ocenili działania Rządu w zakresie dialogu społecznego. Poinformowali oni, że "trzy reprezentatywne centrale związków zawodowych zawieszają swój udział w pracach Trójstronnej Komisji do Spraw Społeczno-Gospodarczych, Wojewódzkich Komisjach Dialogu Społecznego oraz wszystkich Trójstronnych Zespołach Branżowych". Należy zwrócić uwagę na fakt, że krytyka ze strony związków zawodowych dotyczyła konkretnych rozwiązań

${ }^{28}$ M. Pliszkiewicz, Zbiorowe stosunki pracy w krajach Europy Środkowej $i$ Wschodniej (analiza porównawcza), [w:] Trójstronność i zbiorowe stosunki pracy w krajach Europy Środkowej $i$ Wschodniej (stan obecny i perspektywy), red. E. Sobótka, Biblioteka Dialogu Społecznego MPIPS, Warszawa 1994, s. 23-31.

${ }^{29}$ Ibidem.

30 A. Bączkowski, Czego wymaga dialog społeczny?, „Życie Gospodarcze” 1993, nr 40, s. I; E. Sobótka, Rola Trójstronnej Komisji do Spraw Społeczno-Gospodarczych w rozwoju zbiorowych stosunków pracy w Polsce, [w:] Polskie prawo pracy i zbiorowe stosunki pracy w okresie transformacji, red. M. Seweryński, Biblioteka Dialogu Społecznego MPIPS, Warszawa 1995, s. $81-82$.

31 Ustawa z dnia 6 lipca 2001 r. o Trójstronnej Komisji do Spraw Społeczno-Gospodarczych i wojewódzkich komisjach dialogu społecznego (DzU z dnia 18 września 2001 r. z późn. zm.). 
legislacyjnych lub ich braku oraz odmowy zorganizowania referendum. Nie formułowano natomiast zastrzeżeń dotyczących konkretnych przepisów ustawy o Komisji Trójstronnej i konieczności ich zmiany.

Wymienione centrale związków zawodowych w dniu 10 października 2013 r. zorganizowały debatę poświęconą roli i przyszłości dialogu społecznego w Polsce, do udziału w której zaproszono byłych przewodniczących Trójstronnej Komisji, przedstawicieli nauki, ekspertów związkowych oraz osoby specjalizujące się $\mathrm{w}$ tematyce dialogu społecznego. Przedstawiciele organizacji pracodawców i rządu nie zostali zaproszeni. Celem debaty, zgodnie z tezami na zaproszeniu, miało być „wypracowanie wspólnego stanowiska $\mathrm{w}$ zakresie niezbędnych zmian $\mathrm{w}$ dialogu, kompetencji i składu jego instytucji, finansowania, a także wzajemnych relacji partnerów". W czasie tej debaty nie poddano krytyce konkretnych rozwiązań obowiązującej ustawy o Komisji Trójstronnej, ale powtarzano, że konieczna jest nowa ustawa regulująca nową instytucję dialogu na miejsce Komisji Trójstronnej. Jeżeli jakaś instytucja prawna nie funkcjonuje należycie, to nie zawsze jest to wynikiem złej regulacji prawnej.

Wyrażane opinie, że nowe przepisy zapewnią lepsze funkcjonowanie dialogu społecznego budzą wątpliwości. Pamiętam wypowiedzi partnerów społecznych w czasie, gdy Komisja Trójstronna działała na podstawie 470 Uchwały Rady Ministrów ${ }^{32}$, wyrażające nadzieję, że znacząco poprawi się poziom dialogu społecznego, gdy będzie on uregulowany ustawą. Nadzieje te nie ziściły się. Wiadomo, że to nie same przepisy prawne decydują o jakości dialogu społecznego.

Partnerzy społeczni, członkowie Komisji Trójstronnej przygotowali i w styczniu 2015 r. przedstawili propozycje zmian w systemie dialogu społecznego $^{33}$. Na tej podstawie został przygotowany, wspólnie z MPiPS, Projekt ustawy o Radzie Dialogu Społecznego i innych instytucjach dialogu społecznego ${ }^{34}$.

Rozwiązania prawne dotyczące Komisji Trójstronnej i projektowanej Rady Dialogu Społecznego powinny być przeanalizowane w sposób usystematyzowany na podstawie jasnych kryteriów. Takimi kryteriami są warunki dialogu społecznego. Jeżeli, jak twierdzą partnerzy społeczni, obecna formuła prawna wyczerpała się, oznacza to, że nie wszystkie warunki są przestrzegane i dlatego warto je przedstawić i omówić.

${ }^{32}$ Uchwała Rady Ministrów nr 7 z 15 lutego 1994 r. w sprawie powołania Trójstronnej Komisji do Spraw Społeczno-Gospodarczych.

${ }^{33}$ Patrz na ten temat Z. Żurek, Co dalej z dialogiem społecznym? O projekcie ustawy o Radzie Dialogu Społecznego i nie tylko, „Dialog. Pismo Dialogu Społecznego” 2015, nr 2, ss. $44-49$.

${ }^{34}$ Patrz strona internetowa: www.senat.gov.pl (druk Sejmowy nr 3519; druk Senacki nr 965). 


\section{Warunki dialogu społecznego}

W tej części przedstawię warunki funkcjonowania trójstronnego dialogu społecznego w Polsce na podstawie doświadczeń Międzynarodowej Organizacji Pracy (MOP). W okresie tworzenia w Polsce zbiorowego prawa pracy i budowania struktur dialogu społecznego na początku lat dziewięćdziesiątych, korzystaliśmy z wydajnej pomocy finansowej i merytorycznej Wspólnot Europejskich i MOP. Warto przypomnieć Projekt „Dialog społeczny" ${ }^{35}$ realizowany w ramach Programu PHARE-90 z aktywnym udziałem ekspertów MOP. Wtedy poświęcaliśmy bardzo dużo uwagi warunkom, których spełnienie było konieczne, aby zbudować system dialogu społecznego w Polsce ${ }^{36}$. Obecnie warto sprawdzić, czy warunki te są realizowane i w ten sposób ocenić regulację prawną i funkcjonowanie dialogu społecznego w praktyce.

Międzynarodowa Organizacja Pracy (MOP) działa opierając się na zasadzie trójstronności ${ }^{37}$. Według podanej przez nią definicji, dialog społeczny obejmuje wszystkie formy negocjacji, konsultacji lub po prostu wymiany informacji pomiędzy reprezentantami rządów, pracodawców i pracowników, w sprawach dotyczących polityki gospodarczej i społecznej, ważnych dla wszystkich trzech partnerów ${ }^{38}$.

Długa i bogata praktyka Międzynarodowej Organizacji Pracy pokazuje, że istnieją określone warunki, które muszą być spełnione, aby dialog społeczny mógł istnieć i należycie spełniać swoją funkcję w praktyce. Można je sformułować na podstawie Konstytucji MOP, Deklaracji Filadelfijskiej (1944), Deklaracji MOP dotyczącej podstawowych zasad i praw w pracy (1998), Deklaracji MOP dotyczącej sprawiedliwości społecznej na rzecz uczciwej globalizacji (2008) oraz licznych aktów prawnych

35 Patrz E. Sobótka, Dialog społeczny. Założenia, realizacja, perspektywy, [w:] Trójstronność i zbiorowe stosunki pracy w krajach Europy Środkowej i Wschodniej (stan obecny i perspektywy), red. E. Sobótka, Biblioteka Dialogu Społecznego MIPS, Warszawa 1994, ss. 13-22.

${ }^{36}$ E. Sobótka, Trójstronność pilnie poszukiwana, „Polityka Społeczna” 1992, nr 7, s. 35 i 36; eadem, Ustapić, by zyskać, "Życie Gospodarcze” 1992, nr 26, s. 10; eadem, Na gruncie partnerstwa, "Życie Gospodarcze” 1992, nr 50, s. 17 oraz eadem, Zbiorowe stosunki pracy w Polsce, „Vademecum Przedsiębiorcy i Podatnika” 1995, nr 7/8 (14/15); A. Bączkowski, Czego wymaga dialog społeczny, "Życie Gospodarcze"1993, nr 40, s. I; A. Pankert, Trzy warunki, „Życie Gospodarcze” 1993, nr 40, s. III; G. Casale, Autonomia stron, [w:] Trójstronność i zbiorowe stosunki pracy w krajach Europy Środkowej i Wschodniej..., s. 99-101.

${ }_{37}$ Patrz L. Florek, M. Seweryński, Międzynarodowe prawo pracy, IWZZ, Warszawa 1988, s. 47-50.

${ }^{38}$ Le dialogue social tripartite au niveau national. Guide de l'OIT pour une meilleure gouvernance, Genève 2013, s. 12 oraz Dialog społeczny. Podręcznik edukacyjny zwiazków zawodowych, International Training Centre of the International Labour Organization, Turyn 2012 (strona Internetowa www.itcilo.org). 
i innych dokumentów Międzynarodowej Organizacji Pracy (MOP), dotyczących zbiorowego prawa pracy i dialogu społecznego ${ }^{39}$. Można mówić o dwóch rodzajach czy grupach warunków, które przedstawię poniżej. Są to warunki ustrojowe (4.1) i warunki skutecznego dialogu (4.2).

\subsection{Warunki ustrojowe}

Dialog społeczny może istnieć i należycie się rozwijać, jeżeli spełnione są określone warunki o charakterze ustrojowym. Konieczne jest istnienie demokratycznego ustroju, w którym respektowane są prawa i wolności człowieka, w tym prawo do swobodnego zrzeszania się. Niezbędne jest też istnienie gospodarki rynkowej i rynku pracy, na którym mogą występować partnerzy społeczni: związki zawodowe i inni reprezentanci pracowników z jednej strony oraz pracodawcy i ich organizacje z drugiej.

Zgodnie z art. 2 Konwencji MOP nr 87, pracownicy i pracodawcy, bez jakiegokolwiek rozróżnienia, mają prawo, bez uzyskania uprzedniego zezwolenia, tworzyć organizacje według swego uznania, jak też przystępować do tych organizacji, z jednym zastrzeżeniem stosowania się do ich statutów. W wykonywaniu tych uprawnień powinni przestrzegać obowiązujących w kraju przepisów prawnych (art. 8 ust. 2), a ustawodawstwo krajowe nie powinno naruszać gwarancji przewidzianych w Konwencji.

Prawo swobodnego zrzeszania się jest uznawane za podstawowe prawo człowieka w wielu aktach prawa międzynarodowego. Jest ono też jedną z zasad zawartych w Konstytucji RP (art. 59 ust. 1). Szczegółowo prawo to określone jest w art. 2 i 3 ustawy o związkach zawodowych i art. 1 ustawy o organizacjach pracodawców.

Warto podkreślić istnienie następującej współzależności: dialog społeczny wymaga spełnienia wymienionych warunków politycznych i ekonomicznych, a jednocześnie sam w sobie sprzyja demokracji i rozwojowi ekonomicznemu, ograniczając konflikty zbiorowe lub umożliwiając ich rozwiązywanie ${ }^{40}$.

Spełnienie warunków ustrojowych sprawia, że w danym kraju mogą istnieć partnerzy społeczni. Oczywiście nie wystarcza sama taka teoretyczna możliwość. Wymienieni partnerzy społeczni muszą w praktyce

${ }^{39}$ Patrz M. Pliszkiewicz, E. Sobótka, Dialog społeczny. Instytucje, regulacje prawne, praktyka. Polskie rozwiązania na tle porównawczym, [w:] Regionalna szkoła dialogu społecznego. Przewodnik. Perspektywy regionalnego dialogu społecznego w Polsce - w poszukiwaniu modelu, Ed. TNOiK, Gdańsk 2000, s. 25 i 26.

${ }^{40}$ Résolution de l'Organisation internationale du Travail concernant la consultation tripartite au niveau national sur la politique économique et sociale, Genève 1996, [w:] Syndicats et dialogue social : situation actuelle et perspectives d'avenir, red. M. Ozaki et M. Rueda, „Education ouvrière" 2000, vol. 3, Numéro 120, Annexe IV. 
powołać związki zawodowe i organizacje pracodawców, a w przypadku dialogu trójstronnego Państwo musi wyrazić chęć uczestniczenia w dialogu z tymi organizacjami.

\subsection{Warunki skutecznego dialogu}

Drugą grupę stanowią warunki, które muszą być spełnione, aby dialog trójstronny mógł być skutecznie prowadzony. Warunki niezbędne dla istnienia takiej trójstronności dotyczą podmiotów biorących udział w dialogu trójstronnym (4.2.1) oraz przedmiotu tego dialogu (4.2.2). Ograniczone ramy niniejszego rozdziału nie pozwalają na szerokie przedstawienie wszystkich zagadnień związanych z tymi warunkami ${ }^{41}$. Jakie są wstępne warunki niezbędne dla owocnego dialogu społecznego? Istnienie partnerów społecznych, uznanych za silnych i wolnych, którzy w nim uczestniczą na zasadach pełnej niezależności. Partnerzy ci, prowadząc między sobą dialog, uczestniczą w podejmowaniu decyzji, umożliwiają stworzenie atmosfery pokoju, by rozwiązać konflikty interesów w duchu koncyliacji nawet $\mathrm{w}$ razie zróżnicowanych punktów widzenia i w ten sposób zmniejszać poczucie niemożności obywateli ${ }^{42}$. Dialog ten ma szczególne znaczenie $\mathrm{w}$ razie zmiany ustroju danego kraju na demokratyczny, oparty na ich rzeczywistym uczestnictwie.

\subsubsection{Warunki dotyczące podmiotów dialogu społecznego}

\section{Odrębność organizacyjna}

Wszystkie strony dialogu społecznego powinny być wystarczająco silne i dobrze zorganizowane.

Związki zawodowe, organizacje pracodawców i państwo muszą stanowić trzy odrębne, niezależne strony, o wyraźnie określonych funkcjach; wszystkie strony powinny być wystarczająco silne i dobrze zorganizowane; partnerzy społeczni muszą mieć wolę współpracy; trwały pokój społeczny osiąga się przy wzajemnie akceptowanej równowadze partnerów ${ }^{43}$.

Partnerzy społeczni winni posiadać struktury organizacyjne i stosować właściwe mechanizmy działania ${ }^{44}$. Odrębność organizacyjna pozwala na zachowanie autonomii związków zawodowych wobec państwa, wobec partii politycznych, wobec innych grup (klas) socjalnych ${ }^{45}$.

${ }^{41}$ Szerzej na ten temat M. Pliszkiewicz w: M. Pliszkiewicz, E. Sobótka, Dialog społeczny. Instytucje, regulacje prawne, praktyka..., s. 46-49 oraz Dialog społeczny, [w:] Dialog społeczny z korzyścia dla pracowników, red. M. Pliszkiewicz, Wyd. „Karbon sp. z o.o.”, Katowice 2010, s. 28-31.

42 Syndicats et dialogue social..., s. V.

43 A. Pankert, Trzy warunki, "Życie Gospodarcze" 1993, nr 40, s. III.

${ }^{44}$ Ibidem; Syndicats et dialogue social...

${ }^{45}$ J.-M. Verdier, Syndicats et droit syndical, vol. I, Libera, structures, action, [w:] Droit du travail, II Wyd. Direction G.H. Camerlynck, Dalloz, Paris 1987, s. 44 i 45. 


\section{Samodzielność (samorząność)}

Zgodnie $\mathrm{z}$ art. 3 ust. 1 Konwencji MOP nr 87 organizacje pracowników i pracodawców mają prawo opracowywania swych statutów i regulaminów wewnętrznych, swobodnego wybierania własnych przedstawicieli, powoływania swego zarządu, działalności oraz układania swego programu działania. Zasada ta jest szczegółowo określona przepisami art.art. 1, 9, 10 i 11 ustawy o związkach zawodowych i art. 3 ustawy o organizacjach pracodawców.

\section{Niezależność}

Zgodnie $\mathrm{z}$ art. 3 ust. 2 Konwencji MOP nr 87 władze publiczne powinny powstrzymać się od wszelkiej interwencji, która ograniczałaby prawo do samorządnego działania. Związek zawodowy i organizacja pracodawców są niezależni w swojej działalności statutowej od pracodawców, administracji państwowej i samorządu terytorialnego oraz od innych organizacji (art. 1 ust. 2 ustawy o związkach zawodowych i art. 3 ustawy o organizacjach pracodawców). Niezależność związku zawodowego oznacza także niezależność organizacyjna i finansową.

\section{Reprezentatywność}

Reprezentatywność związku zawodowego lub organizacji pracodawców oznacza ich szczególną zdolność do występowania w określonych sprawach w zbiorowych stosunkach pracy, a w szczególności w charakterze strony $\mathrm{w}$ układach i porozumieniach zbiorowych oraz $\mathrm{w}$ sporach zbiorowych pracy ${ }^{46}$.

Chodzi o jak najlepszą reprezentację praw i interesów w warunkach rzeczywiście istniejącego pluralizmu organizacji związków zawodowych i pracodawców ${ }^{47}$.

\section{Kompetencje}

Warunek ten należy rozumieć w obydwu znaczeniach tego słowa. Zarówno jako zakres wiedzy, umiejętności w dziedzinie dialogu społecznego, jak i jako zakres uprawnień, kompetencji do określonego działania. „Podstawowym, wstępnym warunkiem rozwoju dialogu społecznego jest wiedza o tym, czym jest dialog społeczny, kto ma kompetencje w tej dziedzinie i jakie one są oraz jakie są formy, warunki i cele dialogu społecznego" ${ }^{\prime 48}$.

${ }^{46}$ M. Pliszkiewicz, M. Seweryński, Problemy reprezentatywności w zbiorowych stosunkach pracy, „Państwo i Prawo” 1995, nr 9, s. 3-13.

47 Szerzej na ten temat w ujęciu porównawczym - opracowanie Reprezentatywność partnerów społecznych w zbiorowych stosunkach pracy, red. E. Sobótka, M. Pliszkiewicz, Biblioteka Dialogu społecznego MPiPS, Warszawa 1996.

${ }^{48}$ Dialog jest rozmowa, która ma przynieść rozwiąanie problemu, rozmowa z M. Pliszkiewiczem, „Kompania Węglowa, Gazeta Firmowa” 2011, nr 3 (marzec), s. 20 i 21. 
Konieczne jest dokładne określenie zakresu kompetencji wszystkich stron dialogu społecznego. Szczególnie ważne jest rozgraniczenie kompetencji o charakterze stanowiącym i opiniodawczym.

\section{Równowaga sił $i$ istnienie woli wspólnych uzgodnień}

Te dwa warunki warto omówić łącznie. Spełnienie warunku równowagi sił z pewnością ułatwia prowadzenie dialogu społecznego, zwłaszcza $\mathrm{w}$ trakcie rokowań zbiorowych i rozwiązywania sporów zbiorowych. Powstaje jednak pytanie, czy równowaga sił miedzy partnerami społecznymi stanowi warunek sine qua non dialogu społecznego. Za takim stanowiskiem opowiadali się zwłaszcza przedstawiciele pracodawców na posiedzeniu Komisji przygotowującej tekst Rezolucji MOP w roku 1996. W powołanym zespole redakcyjnym odbyła się żywa dyskusja na ten temat. Uznano, że nie zawsze tak musi być. Oponentów przekonał argument dotyczący Paktu o Przedsiębiorstwie Państwowym w Trakcie Przekształcania, podpisanego w Polsce w 1993 r. mimo ogromnej przewagi sił związków zawodowych w stosunku do niewielkiej, dopiero powstającej Konfederacji Pracodawców Polskich. Było to możliwe ze względu na istnienie ogromnej woli wspólnych uzgodnień po stronie wszystkich stron tego Paktu.

\subsubsection{Warunki dotyczące przedmiotu dialogu społecznego}

Eksperci MOP, współpracujący w realizacji Projektu Dialog społeczny. Założenia, realizacja, perspektywy ${ }^{49}$, wymieniali następujące warunki dotyczące przedmiotu dialogu społecznego: istnienie pola do dialogu, określenie przedmiotu i możliwość prowadzenia dialogu. Jeśli bowiem chodzi o przedmiot dialogu społecznego i dialogu trójstronnego, to ważne jest, aby gospodarka była otwarta, taka, że „,jest coś do rokowania” dla partnerów dialogu trójstronnego, że Państwo ogranicza się do zakreślenia ram dialogu w dziedzinie stosunków społeczno-ekonomicznych, podlegających kompetencji tych partnerów ${ }^{50}$.

\section{Podsumowanie}

Oprócz wymienionych wyżej warunków skutecznego dialogu społecznego konieczne jest, aby partnerzy społeczni dysponowali określoną wiedzą i informacjami na temat tego dialogu, aby stosować określone

49 Patrz wyżej przyp. 35.

50 A. Pankert, Po co negocjacje trójstronne, [w:] E. Sobótka (red.), Trójstronność i zbiorowe stosunki pracy..., s. 88; G. Casale, Autonomia stron..., s. 99 oraz E. Sobótka, Rady Gospodarczo-Społeczne w krajach Unii Europejskiej jako zinstytucjonalizowana forma dialogu społecznego, „Praca i Zabezpieczenie Społeczne” 1994, nr 10-11, s. 2. 
strategie, prowadzić regularnie konsultacje i negocjacje, by nie działać od przypadku do przypadku ${ }^{51}$.

Należy podkreślić, że warunki te powinny być realizowane łącznie. Z pewnością nie wszystkie wymienione warunki dotyczące trójstronnego dialogu społecznego są w całości spełniane. Można wskazać tytułem przykładu wypowiedzi na potwierdzenie takiego stanu rzeczy. W czasie Międzynarodowej Konferencji z okazji 15-lecia Trójstronnej Komisji w 2009 r. zwracano uwagę na brak wystarczającej niezależności finansowej i organizacyjnej tej Komisji, obsługiwanej przez MPiPS. Wiele zastrzeżeń i słów krytyki na temat działalności Komisji wypowiadano w czasie realizacji Projektu Systemowego: Poprawa funkcjonowania systemu dialogu społecznego oraz wzmocnienie instytucji i uczestników dialogu społecznego $\mathrm{w}$ ramach Poddziałania 5.5.1. PO KL ${ }^{52}$. Został on zrealizowany przez Departament Dialogu i Partnerstwa Społecznego Ministerstwa Pracy i Polityki Społecznej, w okresie od 1 lipca 2008 do 31 grudnia 2009 r. Projekt ten składał się z trzech komponentów (działań). W ramach pierwszego działania przewidziano „Przeprowadzenie analizy stanu dialogu społecznego oraz opracowanie rekomendacji dla jego zmian". Drugie działanie obejmowało „Opracowanie modelowego systemu kształcenia w zakresie dialogu społecznego" 53 , a trzecie "Stworzenie koncepcji wsparcia instytucjonalnego polskich uczestników dialogu społecznego" ${ }^{\prime \prime 4}$ opartej na dobrych praktykach stosowanych w krajach Unii Europejskiej. O przeszkodach, które napotyka Komisja Trójstronna, pisano w publikacjach będących wynikiem tego Projektu ${ }^{55}$.

Partnerzy społeczni sa, w zasadzie, niezależni i samorządni, ale z pewnością nie są jeszcze wystarczająco silni i dobrze zorganizowani. I nie ma między nimi niezbędnej równowagi. Pracodawcy i ich organizacje są bez wątpienia słabsze niż związki zawodowe. Związki zawodowe mają silną pozycję w sektorze państwowym, ale są praktycznie nieobecne w sektorze prywatnym. Trzeba też zauważyć pewne rozdrobnienie organizacji związkowych i znaczące obniżenie się poziomu uzwiązkowienia. W tych warunkach powstaje wiele problemów związanych z reprezentatywnością związków zawodowych.

51 Syndicats et dialogue social..., s. V.

52 Priorytet V Programu Operacyjnego Kapitał Ludzki - Dobre Rządzenie, Działanie 5.5. Informacje nt. Projektu www.dialog.gov.pl.

${ }^{53}$ Patrz Modelowy system kształcenia w zakresie dialogu społecznego, red. S. Portet, R. Towalski, Instytut Spraw Publicznych, Warszawa 2009.

${ }^{54}$ Patrz W kierunku dialogu opartego na wiedzy, red. A. Zybała, Ministerstwo Pracy i Polityki Społecznej, Centrum Partnerstwa Społecznego Dialog, Warszawa 2009.

55 J. Gardawski, Dialog społeczny w Polsce. Historia, teoria, praktyka, MPiPS, Warszawa 2009, s. 245 i nast. 
Trudnym problemem jest identyfikacja partnerów społecznych. Przeszkodą jest tu wiązanie się z konkretnym ugrupowaniem politycznym ${ }^{56}$. Związki zawodowe często nie potrafią oddzielić działalności związkowej od politycznej. Utrudnia to wyraźnie prowadzenie związkowej działalności statutowej. Innym jeszcze problemem jest poziom odpowiedzialności partnerów i często występująca różnica między deklaracjami i polityczną wolą skutecznego dialogu, który nie zawsze jest uczciwy i rzeczowy.

Ocena rozwiązań prawnych i praktyki trójstronnego dialogu społecznego w Polsce opartej na warunkach tego dialogu jest propozycją metodologiczną która pozwala na wprowadzenie pewnego porządku i na systematyczną analizę. Nasuwają się pewne wnioski ogólne. Otóż, nawet gdy niektóre warunki nie są spełniane, dialog społeczny może przynosić efekty. Regulacja prawna jest ważna, ale dialog społeczny może być prowadzony nie tylko w ramach instytucji, na podstawie przepisów prawnych, ale również ad hoc, z woli partnerów społecznych. Przykładem takiego dialogu zakończonego sukcesem był Pakt o Przedsiębiorstwie Państwowym w trakcie Przekształcania z 1993 r.

Przeszkodą $\mathrm{w}$ prowadzeniu skutecznego dialogu nie są więc przepisy prawne. Przecież w ramach tych krytykowanych przepisów ustawy o Komisji Trójstronnej odnotowano istotny sukces. Partnerzy społeczni, członkowie tej Komisji, przygotowali w 2009 r., w formie dezyderatu, pakiet obejmujący trzynaście najistotniejszych z ich punktu widzenia zagadnień niezbędnych do przeciwdziałania kryzysowi ekonomicznemu. Obawiam się, że nowa ustawa o Radzie Dialogu Społecznego nie spowoduje sama z siebie podniesienia poziomu dialogu społecznego.

Warto jednak zapamiętać, że zgodnie z doświadczeniami MOP, system bezpośrednich konsultacji, negocjacji i uzgodnień dokonywanych przez uczestników dialogu społecznego może przybierać w praktyce różne formy. „Wszędzie jednak o możliwości funkcjonowania trójstronności przesądzają:

- samodzielność podmiotów i ich wzajemna niezależność,

- określenie przedmiotu negocjacji i - co nie mniej ważne

- istnienie politycznej woli wspólnych uzgodnień" ${ }^{57}$.

Dialog społeczny i praktyka trójstronności między rządami oraz reprezentatywnymi organizacjami pracowników i pracodawców w kraju i ponad jego granicami, są obecnie jeszcze istotniejsze w kontekście wypracowania dobrych rozwiązań, a także budowania spójności społecznej oraz rządów prawa, między innymi przez międzynarodowe standardy pracy ${ }^{58}$.

${ }^{56}$ Ibidem, s. 246.

${ }^{57}$ E. Sobótka, Ustapić, by zyskać..., s. 10 oraz Le dialogue social tripartite dans les relations industrielles lors de la transition en Pologne, [w:] Développement de la démocratie en Europe, Programme PHARE, Confrontation, Paris 1993/1994, s. 16.

${ }^{58}$ Deklaracja MOP dotycząca sprawiedliwości społecznej na rzecz uczciwej globalizacji (2008). 
Trójstronny dialog społeczny nie powinien być regulowany prawnie w oderwaniu od innych rodzajów dialogu społecznego (autonomicznego i wielostronnego). Jest on bowiem immanentną częścią dialogu społecznego w ogóle, istniejącego na różnych poziomach: zakładowym, lokalnym, regionalnym, branżowym, krajowym i europejskim. Należy żałować, że partnerzy społeczni nie wystąpili z żądaniem całościowego uregulowania tej dziedziny w ramach Kodeksu Zbiorowego Prawa Pracy.

\section{Bibliografia}

Bączkowski A., Czego wymaga dialog społeczny, „Życie Gospodarcze” 1993, nr 40. Florek L., Seweryński M., Międzynarodowe prawo pracy, IWZZ, Warszawa 1988.

Javillier J.-C., Dynamique des relations professionelles et évolution du droit du travail, [w:] Le droit collectif du travail (questions fondamentales - évolutions récentes), Etudes en hommage à Madame Hélène Sinay, eds N. Aliprantis, F. Kessler, Frankfurt am Main-BerlinBern-New York-Paris-Wien 1994.

Kodeks pracy. Zbiorowy kodeks pracy, Wyd. Uniwersytetu Ekonomicznego w Katowicach, Katowice 2010.

Mazowiecki T., Le temps de produire la démocratie en Pologne, [w:] Démocratie, culture et développement en Europe Centrale, Ed : Confrontqtions. Société, culture, foi, Paris 1992.

Nowacki J., Pliszkiewicz M., Rosner J., Seweryński M., Szubert W., Zieliński T., Kierunki reformy prawa pracy. Założenia ogólne, Instytut Wydawniczy Związków Zawodowych, Wyd. I i II, Warszawa 1981.

Ozaki M., Rueda M. (eds), Syndicats et dialogue social: situation actuelle et perspectives d'avenir, „Education ouvrière” 2000, vol. 3, nº 120.

Pankert A., Trzy warunki, „Życie Gospodarcze” 1993, nr 40.

Pliszkiewicz M., Dialog społeczny z korzyścia dla pracowników, red. M. Pliszkiewicz, Wyd. „Karbon sp. z o.o.", Katowice 2010.

Pliszkiewicz M., Dialogue social en Pologne, [w:] Des liens et des Droits, Mélanges en l'honneur de Jean-Pierre Laborde, Ed. Dalloz, Paris 2015.

Pliszkiewicz M., Podstawowe problemy rozwoju prawa pracy w Europie Środkowo-Wschodniej, [w:] Nowy ład pracy w Polsce i w Europie, red. M. Matey, Wydawnictwo Naukowe „Scholar", Warszawa 1997.

Pliszkiewicz M., Vers de nouvelles relations professionneles En Europe de l'Est, [w:] Les relations sociales dans les pays de l'Est, Ed. Institut National du Travail, de l'Emploi et de la Formation Professionnelles, Direction M. Pliszkiewicz, Paris 1994.

Pliszkiewicz M., Zbiorowe stosunki pracy w krajach Europy Środkowej i Wschodniej (analiza porównawcza), [w:] Trójstronność i zbiorowe stosunki pracy w krajach Europy Środkowej $i$ Wschodniej (stan obecny i perspektywy), red. E. Sobótka, Biblioteka Dialogu Społecznego MPIPS, Warszawa 1994.

Portet S., Towalski R. (red.), Modelowy system kształcenia w zakresie dialogu społecznego, Instytut Spraw Publicznych, Warszawa 2009.

Rivero J., Savatier J., Droit du travail, PUF, Paris 1991.

Seweryński M., Dialog społeczny. Współzależność gospodarki i prawa pracy, [w:] Referaty na VI Europejski Kongres Prawa Pracy i Zabezpieczenia Społecznego, Wydawnictwo Naukowe „Scholar", Warszawa 1999. 
Seweryński M., Les particularités du syndicalisme des pays de l'Est et les tendances récentes dans ce domaine, "Revue Internationale de Droit Comparé" 1990, n 1.

Seweryński M., Prospects for the Development of Labour Law and Social Security Law in Central and Eastern Europe in the Twenty-First Century, [w:] $5^{\text {th }}$ European Regional Congress for Labour Law and Social Security. General Reports, Leiden, The Netherlands 1996.

Seweryński M., Uwagi o efektywności prawa pracy, [w:] Księga Pamiątkowa w piąta rocznice śmierci Profesora Andrzeja Kijowskiego, red. Z. Niedbała, LEX Wolters Kliwer business, Warszawa 2010.

Skąpski M., Ślebzak K. (red.), Aksjologiczne podstawy prawa pracy i ubezpieczeń społecznych, Wyd. Ars boni et aequi, Poznań 2014.

Sobótka E., Dialog społeczny. Założenia, realizacja, perspektywy, [w:] Trójstronność i zbiorowe stosunki pracy w krajach Europy Środkowej $i$ Wschodniej (stan obecny i perspektywy), red. E. Sobótka, Biblioteka Dialogu Społecznego MIPS, Warszawa 1994.

Sobótka E., Le dialogue social tripartite dans les relations industrielles lors de la transition en Pologne, [w:] Développement de la démocratie en Europe, Programme PHARE, Confrontation, Paris 1993/1994.

Sobótka E., Na gruncie partnerstwa, „Życie Gospodarcze” 1992, nr 50.

Sobótka E., Rady Gospodarczo-Społeczne w krajach Unii Europejskiej jako zinstytucjonalizowana forma dialogu społecznego, "Praca i Zabezpieczenie Społeczne” 1994, nr 10-11.

Sobótka E., Trójstronność pilnie poszukiwana, „Polityka Społeczna” 1992, nr 7.

Sobótka E., Ustapić, by zyskać, „Życie Gospodarcze” 1992, nr 26.

Sobótka E., Zbiorowe stosunki pracy w Polsce, "Vademecum Przedsiębiorcy i Podatnika" 1995, $\mathrm{nr} 7 / 8(14 / 15)$.

Szubert W., Histoire du droit et les recherches sur le droit contemporain, "Czasopismo Prawno-Historyczne" 1979, t. XXXI, z. 1.

Szubert W., Refleksje nad modelami prawa pracy, „Państwo i Prawo” 1989, nr 10.

Szubert W., Zarys prawa pracy, PWN, Warszawa 1976.

Verdier J.-M., Syndicats et droit syndical, vol. I, Libera, structures, action, [w:] Droit du travail, II Wyd. Direction G.H. Camerlynck, Dalloz, Paris 1987.

Zieliński T., Interpretacja historyczna w porównawczym prawie pracy, [w:] Studia z prawa pracy. Dla uczczenia 50-lecia działalności naukowej Profesora Doktora Wacława Szuberta, PWN, Warszawa-Łódź 1988.

Zieliński T., Podstawy rozwoju praw pracy, rozdz. VI - Czynnik historyczny w rozwoju prawa pracy, PWN, Warszawa-Kraków 1988.

Zieliński T., Prawo pracy. Zarys systemu, cz. I, Ogólna, PWN, Warszawa-Kraków 1986.

Zybała A. (red.), W kierunku dialogu opartego na wiedzy, Ministerstwo Pracy i Polityki Społecznej, Centrum Partnerstwa Społecznego Dialog, Warszawa 2009.

Żurek Z., Co dalej z dialogiem społecznym? O projekcie ustawy o Radzie Dialogu Społecznego i nie tylko, „Dialog. Pismo Dialogu Społecznego” 2015, nr 2.

\section{Conditions for the Tripartite Social Dialogue}

\section{Summary}

Any discussion about the future of labour law in Poland requires an assessment of the current state of the law and a discussion on the need for change. This is because codification reflecting changes to the political, social and economic order after 1989 has so far not been possible to achieve. 
It is currently difficult to expect a quick codification. However, an assessment of the individual institutions of labour law can be made gradually. The subject of this chapter is the conditions for tripartite social dialogue. This is a topical issue. Representative social partners, members of the Tripartite Commission, are demanding deep legislative changes in this field. They believe that the current legislative formula has depleted itself, but they provide no information which solutions currently in force need changing due to not working well in practice. The social partners, members of the Tripartite Commission, have jointly with the Ministry of Labour and Social Affairs prepared the draft bill of a new Social Dialogue Board Act.

Regulations and other documents of the International Labour Organization prescribe conditions which need to be fulfilled for successful social dialogue. This chapter present those conditions and attempt to assess whether the legislative change will in practice enable a better application of tripartite social dialogue in Poland. 